\title{
Contractual Restrictions On the Forum
}

\section{G. Merle Bergman*}

SOME loose language has come out of the Second Circuit since 1949 which $\mathcal{S}_{\text {has led some attorneys, and even some courts, to believe that the law }}$ has somehow done an about-face and that it now recognizes the validity of contractual clauses limiting the forum in which a cause of action may be brought, whereas it previously denied validity to such clauses. Such a concept of the present state of the law can only cloud our understanding of the rulings themselves and could prove most harmful to the public interest. It is appropriate, therefore, that we examine the matter at some length, lest we permit the overly broad language of the Second Circuit to influence other courts in their decisions.

Unfortunately the most recent pronouncement on the subject by the United States Supreme Court was in 1874. In Insurance Company v. John F. Morse, ${ }^{1}$ the Court considered the validity of a clause in an insurance contract which required all actions to be brought in the courts of the State of Wisconsin. This clause had been inserted in the contract pursuant to a Wisconsin statute requiring all foreign insurance companies doing business in the state to provide for this kind of restricted venue. The Court held that the clause was invalid and, speaking through Mr. Justice Hunt, had this to say:

Every citizen is entitled to resort to all the courts of the country, and to invoke the protection which all the laws or all those courts may afford him. A man may not barter away his life or his freedom, or his substantial rights ....

That the agreement of the insurance company is invalid upon the principles mentioned, numerous cases may be cited to prove. They show that agreements in advance to oust the courts of the jurisdiction conferred by law are illegal and void ....2

The agreement of the insurance company derives no support from an unconstitutional statute and is void, as it would be had no such statute - been passed. ${ }^{3}$

It is particularly noteworthy that the opinion indicated that courts could not be ousted of their jurisdiction to hear a cause of action because "a man may not barter away ... his substantial rights." In short, at least in 1874, it was considered by the United States Supreme Court that the right of

* Member, Illinois and California Bars.

187 U.S. (20 Wall.) 445 (1874).

2 Id. at 451.

3 Id. at 458. 
every citizen to resort to any forum which had jurisdiction of the cause was a substantial right which he could not barter away. A state could not by special legislation such as that of the State of Wisconsin restrict the bringing of a cause of action to its own forum, nor could the parties by contract do so. It was against public policy to allow the parties to do what the states clearly could not, not because it somehow offended the dignity of the courts, but because "every citizen is entitled to resort to all the courts of the country, and to invoke the protection which all the laws or all those courts may afford him."

Even while Justice Hunt spoke, however, there was a recognized exception to the general rule in the application of the doctrine of forum non conveniens. This, however, was in reality only a quasi-exception. By its application the courts could refuse to hear a case where the residence of the parties, the location or nature of the dehct, and the convenience of the witnesses made it more appropriate for the cause to be heard elsewhere. Since the doctrine of forum non conveniens antedated the doctrine which forbade contractual limitations on the forum, it cannot be regarded as a true exception to the rule expressed in the Insurance Company case.

Naturally when the elements for the application of the doctrine of forum non conveniens appeared in cases which also involved a contractual limitation on the forum, the courts had to decide whether the doctrine was incompatible with the proposition that such contractual limitations were void. They wondered whether they were, in fact, giving effect to the invalid clause when they refused to hear a case. The courts were able to decide, however, that they were not. The agreement was void. But this could not prevent the courts from exercising their discretion under the doctrine of forum non conveniens. If im so doing the terms of the void agreement were carried out, it was not the courts' affair. Any enforcement was clearly indirect. The courts could agree that a citizen was "entitled to resort to all the courts of the country, and to invoke the protection which all the laws or all those courts may afford him," and still recognize that the laws of the country had already estabhshed the fact that no citizen had the right to inconvenience the courts and other parties to the suit by bringing a case to trial in the least convemient forum. The application of the doctrine of forum non conveniens was, therefore, invoked to protect the courts and was not to be taken as a departure from the clear rule that parties could not contract to limit the forum.

Later, by act of Congress and by state court interpretations, another exception to the rule was made. Arbitration clauses were held to be valid and enforceable. If parties agree to be bound by the decision of arbitrators they could not then resort to the courts. But this was not, strictly speaking, a true exception either, because it was not a limitation on the forum, but rather was an agreement to eliminate the need for any forum whatever. 
It came about in the first instance because Congress had decided that a public policy favoring the settlement of disputes by arbitration, and thereby relieving the burden on the courts, was to be preferred to any public policy against restricting the forum. Even after this exception, however, it was still the law that any contractual clause which permitted resort to one court of competent jurisdiction and not to another was invalid. It had to be all or none, and if it were none the alternative had to be arbitration, which was considered adequate to afford full protection to the rights of the parties. If they can be called exceptions at all, the doctrine of forum non conveniens and the recognition of arbitration agreements were clearly the only exceptions to the rule that such clauses were invalid.

In 1930 Judge Learned Hand wrote an opinion in the case of Wood $\&$ Selick, Inc. v. Compagnie Generale Transatlantique, ${ }^{4}$ which contained a classic statement of the rule:

We may at the start lay aside the clauses in the bills of lading, which apparently were intended to confine any litigation over the contracts to a French court. The respondent does not pretend that, so.construed, these would be valid, and it is of course well settled that they would not. 5

There could hardly be a more precise and unequivocal statement of the rule that contractual limitations on the forum are invalid. Indeed, said Judge Hand, this "is . . . well settled." Since the 1949 decision in Krenger v. Pennsylvania R.R., ${ }^{6}$ however, all has been chaos, and it is ironic that the source of the confusion is to be found in a concurring opinion written by this very man, Judge Learned Hand, who is universally acclaimed for his clarity of thought and excellence of approach. It is somewhat difficult to understand how that which was so well settled in 1930 could become unsettled in the space of mineteen years. Certainly nothing happened in the intervening time to deprive a citizen of his right "to resort to all the courts of the country, and to invoke the protection which all the laws or all those courts may afford him." Moreover, nothing happened which would make it appropriate to allow a man "to barter away his substantial rights." We should, therefore, approach Judge Hand's concurring opinion in Krenger with caution.

The Krenger case arose under the Federal Employers' Liability Act, and the question before the court was whether a contract restricting the forum in which the action could be brought was valid. Judge Clark ruled that section 5 of the act invalidated the restrictive clause, ${ }^{7}$ but went on to

443 F.2d 941 (2d Cir. 1930).

5 Id. at 942 .

6174 F.2d 556, 558 (2d Cir. 1949), cert. denied, 338 U.S. 866 (1949).

7 Ibid. It is at least arguable that denial of certiorari was a tacit approval of Judge Clark's ruling. Cf. Grand Trunk Western R.R. v. Boyd, 321 Mich. 693, 33 N.W.2d 120 (1948), rev'd per curiam, 338 U.S. 263 (1949). 
express his opinion as to the general principles that should govern such clauses. He favored a distinction between contracts made prior to the accrual of the cause of action and those made after the cause of action has arisen. ${ }^{8}$ Presumably he would hold the former invalid and the latter valid if general principles were to apply. Since he decided, however, that section 5 of the act governed the decision, he did not develop this point any further. Judge Hand, while concurring in the result, was of the opinion that section 5 did not apply and placed his decision, holding the clause invalid, upon general principles of law. To look to Judge Hand's opinion, therefore, as authority for the proposition that a clause limiting the forum is now valid where before it was not is to presume too much on the reputation of a great judge. Even if we limit his opinion, as it should be, to the mere proposition that a contractual clause restricting the forum may be "enforced" where there has been equality of bargaining power and mutuality of benefit, there seems little justification to treat it as anything more than a further limitation on the historical forum non conveniens exception to the rule.

In delivering his concurring opinion, Judge Hand felt obliged to answer the distinctions which Judge Clark had made, and also to refute the dissent of Judge Swan, who would have held the clause valid and dismissed the action. Judge Hand said, in part:

[B]e the original reasons good or bad, courts have for long looked with strong disfavor upon contracts by which a party surrenders resort to any forum which was lawfully open to him. ${ }^{9}$

This was said in reply to Judge Swan's contention that the court ought to enforce the clause by dismissing the action. Judge Hand decided otherwise and thereby demonstrated the "strong disfavor" with which the courts have always viewed such contracts. Then Judge Hand went on to say:

Since such contracts are almost always made before any claim has arisen, there are few decisions which have considered whether ... the doctrine covers contracts made after a claim arises. There are three decisions which make the distinction. . . . I can see no basis for such a distinction. . . . Whatever the grounds for denying ... the privilege in the [one] ... case, seem to me to deny it in the [other] $\ldots .0^{10}$

Here Judge Hand is answering Judge Clark by arguing that the clause is equally invalid if contracted after the cause of action accrues as it is if contracted before. Judge Hand has certainly the sounder argument on this point if we hark back to Mr. Justice Hunt's statement that a man may not barter away his substantial rights. ${ }^{11}$ If it is a substantial right of the indi-

8174 F.2d 556, 558 (2d Cir. 1949).

9 Id. at 560 .

10 Ibid.

11 See quote in text at note 2, supra. 
vidual to resort to all of the courts open to him, and if he cannot barter away this right, then it makes no difference whether the barter takes place before or after the cause of action accrues. If anything, therefore, Judge Hand has demonstrated thus far in his opinion an even more restrictive interpretation than some courts had been inclined to make.

But Judge Hand then goes on to point out that the rule need not be so strict as to prevent the "enforcement" of restrictive clauses where it is entirely reasonable to enforce them. Clearly he had in mind the forum non convemiens cases, but he has confused the legal community generally by his words because he failed to mention this group of cases by name, and because we are not accustomed to consider the application of the doctrine of forum non conveniens as an "enforcement" of the restrictive clause. To his practical mind it is such an "enforcement," however, and an appreciation of his practical approach to these matters renders his opinion much more meaningful. In his opimion Judge Hand said:

In truth, I do not believe that, today at least, there is an absolute taboo against such contracts at all; in the words of the Restatement, they are invalid only when unreasonable; and Mittenthal v. Mascagni, is a notable instance in which a contract in futuro was held "reasonable." What remains of the doctrine is apparently no more than a general hostility, which can be overcome, but which nevertheless does persist. ${ }^{12}$

His words, clearly, were not carefully chosen. If we refer to section 558 of the Restatement of Contracts on which Judge Hand placed such reliance for his conclusion that these clauses are "invalid only when unreasonable," we find that the Restatement does not quite stand for this proposition. It reads as follows:

A bargain to forego a privilege, that otherwise would exist, to litigate in a Federal Court rather than in a State Court, or in a State Court rather than in a Federal Court, or otherwise to limit unreasonably the tribunal to which resort may be had for the enforcement of a possible future right of action or the time within which a possible future claim may be asserted, is illegal. ${ }^{13}$

What the Restatement says is something different from what Judge Hand has said. The Restatement flatly says that a requirement to litigate in a federal court rather than in a state court, or vice versa, is illegal. It does not talk of reasonableness in this connection. What it really talks of is unreasonableness. It considers it clearly unreasonable to require litigation in one court rather than another, and then goes on to say that other unreasonable limitations on the tribunal are also illegal. Nowhere does it say that these clauses are valid if reasonable, because it has already defined them to be unreasonable. 
If we now turn to the Mittenthal ${ }^{14}$ case cited by Judge Hand, we find a clear application of the doctrine of forum non convemens, the historical exception to the rule we are discussing. In this case the court determined that Italy was the proper forum because of the residence of the parties, the convenience of the witnesses, and other typical forum non conveniens considerations. But then the court went on to discuss the fact that the parties had both been desirous of having such a clause included in the contract at the time that it was bargained for and that there was an equality of bargaining power between them. These latter considerations had never before been specified in a forum non conveniens case, but apparently the court felt that it made a stronger case for the application of the doctrine. And apparently Judge Hand was greatly influenced by these considerations in the Krenger case, as we shall see. At the very least, it is clear that if we look to the authorities he cites for the broad proposition that these clauses are "invalid only when unreasonable," we must reach the conclusion that the authorities cited are more properly cited for the rule that these clauses are always unreasonable except where the doctrine of forum non conveniens may properly be applied. This is perhaps what Judge Hand really meant to say. In any event, we must all agree that the actual decision of the Krenger case, in which decision Judge Hand concurred, was not at all in accord with the proposition that these clauses were valid. Judge Hand concluded his opinion with these words:

For the foregoing reasons, I think that, although $\S 5$ does not bar such contracts, three considerations conspire to take them outside what was decided in Callen v. Pennsylvania R. Co., supra: (1) they are contracts of a kind at which courts have always looked askance; (2) they concern a matter as to which-in some respects at any rate-Congress has shown that it considered the employee to bargain at a disadvantage; (3) that disadvantage is in this instance especially narked and is without any corresponding benefit. ${ }^{15}$

Judge Hand thereupon ruled that jurisdiction be retained and that the clause be held unenforceable.

In the light of these words and this ruling, the concurring opinion of Judge Hand in the Krenger case seems to be poor authority for the succeeding opinions which purport to be based upon it. What Judge Hand appears to have done is to limit the enforcenent of contractual restrictions upon the forum through application of the doctrine of forum non conveniens by requiring the additional criteria suggested in the Mittenthal case. The Callen ${ }^{16}$ case to which he referred involved the question of whether an employee could, under the Federal Employers' Liability Act, enter into an 
agreement to settle his claim. The Court had ruled that he could do so. Judge Hand concluded that it was one thing to settle a claim, but quite another to agree to restrict the forum. One could not be equated with the other, and therefore he believed that the Callen case could not be cited as authority in the Krenger case, and so held in the passage quoted above.

Looking strictly to the court's decision in the Krenger case, rather than to three or four loosely worded sentences taken out of context from Judge Hand's concurring opinion, we find the decision wholly consistent with Judge Hand's 1930 opinion in the Wood \& Selick case that contractual restrictions on the forum are invalid. Judge Hand's failure to mention, either by distinguishing or repudiating his 1930 opinion, leads us to the conclusion that he regarded the 1949 Krenger decision to be entirely consistent with his previous position.

In the Krenger case Judge Hand merely confirmed what was inherent in the earlier Wood \& Selick decision, i.e., that a contract to limit the forum was one at which "courts have always looked askance." And looking askance, he held the clause invalid. While courts would enforce such a clause indirectly by applying the doctrine of forum non convemiens, they would not, in the absence of the application of this doctrine, enforce a contractual limitation on the forum. From the language of the Mittenthal case one may infer that the mere existence of forum non conveniens considerations would not be sufficient grounds for indirectly enforcing the contractual restriction. Where the circumstances of the case are such that the court would apply the doctrine of forum non conveniens had there been no contractual restriction, the restriction would have no effect and the court would exercise its discretion. Where, however, there is doubt as to the applicability of the doctrine, though the elements are present, the Mittenthal case indicated that the court would look to the restrictive provision as an additional factor to be considered in the application of the doctrine and would impose additional requirements of fairness between the parties. And in the Krenger case Judge Hand saw fit to make these additional requirements specific. He argued that a case should be retained in the forum where it appeared that (1) the parties bargained from an unequal position, and (2) there was no equal benefit to the party who bargained at a disadvantage. Such a. rule would certainly be in keeping with Judge Hand's tendency to look behind the form to substance. While courts might say that they were not actually enforcing the restrictive clause when they declined to hear a case, it was apparent that their exercise of discretion certainly had that effect. Judge Hand realistically called this exercise of discretion an "enforcement" of the clause. But it was an enforcement long established in the law. Even so, he was not content to have the court exercise its discretion merely because the other elements were present, where one of the 
parties had been compelled to bargain at a disadvantage, or where there was clearly no corresponding benefit to him in agreeing to such a clause. It seems almost incredible that this highly restrictive interpretation could be cited by so many as authority for the proposition that the rule had been liberalized by Judge Hand.

One such case which purports to follow Judge Hand's concurring opinion is the case of $W m$. H. Muller \& Co., Inc. v. Swedish American Line, Ltd. ${ }^{17}$ This case involved a contract made in Sweden between Swedish corporations, one of which later assigned its rights to an American corporation. The lower court declined jurisdiction. On appeal the decision below was affirmed and the court, speaking through Judge Hincks, said:

[W]e accept the conclusion of Judge L. Hand stated in his concurring opinion in the Krenger case. . . From this it follows that in each case the enforceability of such an agreement depends upon its reasonableness. ... [I] $f$ in the proper exercise of its jurisdiction, by a preliminary ruling the court finds that the agreement is not unreasonable in the setting of the particular case, it may properly decline jurisdiction and relegate a litigant to the forum to which he assented ....

In declining jurisdiction and dismissing the complaint we think he was well within the limits of lawful judicial discretion. ${ }^{18}$

If the court meant by this that a trial court can exercise its discretion in the application of the doctrine of forum non converiens (all the elements of which were present in this case) where the contract was not unfair, using Judge Hand's criteria, then the decision certainly follows the Krenger case. But if the court means to go beyond this and suggest that a clause limiting jurisdiction of the forum will be enforced whether or not the elements for the application of the doctrine of forum non conveniens are present, so long as the contractual clause is not unreasonable, it goes far beyond what was actually decided in the Krenger case, far beyond what the Restatement allows, far beyond what the Supreme Court has ever decided, and far beyond what the facts of the Muller case itself would warrant.

In the Muller case the parties were both Swedish commercial companies enjoying equal bargaiming status, and equally desirous of limiting the forum to Sweden. There was clearly mutuality of benefit as respects the clause. As the court pointed out, the American assignee would stand in no better position than the Swedish assignor. The court then detailed the typical forum non conveniens considerations. As to the original parties, they were residents of Sweden; all witnesses were residents of Sweden; the ship was constructed in Sweden and the issue concerned the serviceability of the ship. Sweden was clearly the most convenient forum for the trial of 
the issue. In spite of the fact, therefore, that some would look to this opinion as authority for the extravagant proposition that clauses limiting the forum are now enforceable where before they were not, the facts of the case make it a typical forum non conveniens ruling with the additional Krenger requirements appended thereto.

Another case whose language may be misleading if the facts are not carefully studied is the case of Chemical Carriers, Inc. v. L. Smit \& Co.'s Internationale Sleepdienst. ${ }^{19}$ Speaking through Judge Bryan, the court said: "It is no longer the law that contractual provisions which purport to limit a jurisdiction which would otherwise attach are void and unenforcible [sic]." ${ }^{20}$ This statement, taken alone and out of context, would seem to support the proposition that the reverse is now true, i.e., that it is now the law that such provisions are valid and enforceable. But the court could hardly have been saying this, since it retained jurisdiction and refused to enforce the clause. Consider these further remarks of the court:

Nevertheless, such agreements, particularly those calling for exclusive jurisdiction in a foreign court, are not looked upon with favor and will not be enforced by the Federal courts if they are unreasonable in themselves or in the effect they may have on the rights of the parties to the dispute. ${ }^{21}$

As the court's ruling must indicate, it was doing nothing more than confirming its long recognized right to apply the doctrine of forum non conveniens in an appropriate case, while at the same time determining that this was not such a case. It would be most unfortunate if the court's loose language, taken out of context, were to be cited in other instances to support the dangerous proposition that such clauses are now vahd and enforceable. That it is being cited for this proposition every day in trial courts is ample reason to undertake a thoroughgoing reappraisal of the Krenger decision which has fathered this loose language and similar language in other cases.

In spite of the claims which are being made by hopeful attorneys for shipping interests and other foreign firms who utilize the restrictive forum clause in their contracts, the law in this area has not been liberahized one iota since 1874. Such contracts are illegal and unenforceable today as they were then. Such contracts will be indirectly enforced through the application of the doctrine of forum non convernens today as they were then. The Krenger decision indicates, however, that the courts will refuse to enforce a restrictive forum clause by means of the doctrine of forum non conveniens unless the court would have applied the doctrine had there been no restrictive forum clause or unless the forum non conveniens elements are at least 
present and the restrictive forum clause was bargained for between equals and confers mutuality of benefit.

It is shocking to think that some courts would look to the Krenger decision and the loose language that has followed it to jeopardize the rights of travelers and shippers and others who contract at a disadvantage. What equality of bargaining power is there for the small shipper, the individual traveler, or the individual insured who finds a restrictive forum clause in his bill of lading, passenger ticket, or contract? What mutuality of benefit is there for these individuals in such a restriction? There is none, and unless we insist upon the letter of the law as it has always been, we will effectively deprive thousands of injured persons of any practical forum for the trial of their causes of action. Only the great companies can afford to try their cases in foreign lands, and the burden of doing so must fall upon them. Common carriers who offer services to those in foreign lands must expect to be sued in those foreign lands, and cannot contract to avoid such suit by means of restrictive forum clauses. These clauses are against public policy as much today as they were in 1874 . Today, as then, every citizen should be entitled to resort to all the courts of his country and to invoke the protection which all the laws or all those courts may afford him. Today, as then, "a man may not barter away his hife or his freedom, or his substantial rights." Today, as then, our courts must rule that a clause depriving a man of his right to resort to any court of competent jurisdiction is against public policy. 